\title{
ПРОЦЕСУАЛЬНІ ПОВНОВАЖЕННЯ СЛІДЧОГО СУДДІ
}

\author{
КОРЕЦЬКА Вікторія Віталї̈вна - суддя Ківерцівського районного суду \\ Волинської області. Луцьк. Україна \\ КОРЕЦЬКИЙ Олег Павлович - начальник відділу Державного бюро \\ розслідування. Київ. Україна \\ УДК 343.125 \\ DOI:10.32782/NP.2020.2.13
}

\begin{abstract}
Проведение ребормы уголовного прочессуального законодательства предоставила новые элементы построения уголовного процесса. Определенъ процессуальные полномочия следователя судьи на стадии досудебного расследования. Предложено судебныи контроль при предоставлении следственнъим судъей постановления в случае ограничения прав и свобод человека в уголовном производстве. Определено, что процессуальнье полномочия следственного судьи, установленнъле действующим законодательством соответствуют международнъим правовъм нормам и обеспеиивают выполнение прав, свобод и гарантий участников уголовного судопроизводства, а также устанавливают процессуальнылй контроль следственного судьи за проведение следственнъих розъскнъхх действий. Предложенъ теоретические аспекть и практическое решение даннъх вопросов и внесения изменений в действующее законодательство.

Ключевъие слова: механизм, ходатайство, следственнъие розыскнъе действия, гарантии, статус, следователь, прокурор, следственнъий судья, участник досудебного расследования.
\end{abstract}

Актуальність статті передбачає розгляд чинного законодавства України та визначення процесуальних повноважень слідчого судді. Новизною чинного КПК України є участь на стадії досудового провадження слідчого судді, який розглядає процесуальні клопотання слідчого, прокурора, що пов'язані з наданням ухвали про проведення слідчих розшукових дій, які тимчасово обмежують процесуальнs права та обов'язки підозрюваного. Держава продовжує реформування правосуддя. Основний зміст реформ включає ліквідацію конституційних декларацій та реальну роботу суду, забезпечення правосуддя на підставі змагальності, диспозитивності.

Метою статті $\epsilon$ визначення процесуальних повноважень слідчого судді на стадії досудового розслідування, запропонування вирішення практичних положень чинного законодавства, які мають, в окремих випадках, теоретичну неузгодженість чинного законодавства України.

Теоретичні положення процесуальної діяльності суду були предметом дискусій 3 боку вчених, які надали елементи удосконалення судової системи, процедури судового розгляду кримінального провадження, застосування гарантій прав та свобод людини і громадянина.

Ю.П. Аленин, К.Д. Анцифиров, М.І. Бажанов, А.О. Богословська, О.I. Бережной, В.Д. Бринцев, М.М. Гродзинський, Ю.М.Грошевой, І.В. Гловюк, Т.М. Добровольска, О.М. Дроздов, А.Д. Зусь, Н.Н. Ковтун, О.М. Овчаренко, О.Г. Яновська та ін. автори визначали процесуальні аспекти судової діяльності у кримінальному процесі на підставі правового застосування закону та верховенства права $[1 ; 2$; $3 ; 4 ; 5 ; 6 ; 8 ; 10 ; 11 ; 12 ; 13 ; 14 ; 17 ; 20]$. 


\section{Кримінальне право, кримінальний процес та криміналістика}

В.Т. Маляренко, О.Г. Яновська вважають, що суддя повинен виконувати свої процесуальні обов'язки на підставі засади справедливості, однак вона практично не вживається у кримінальному процесі [16,с. $15 ; 20]$.

Розглядаючи теоретичні проблеми та практичні питання участі судді на стадії досудового провадження, необхідно зупинитися на визначенні його правового статусу. Якщо статус судді під час судового розгляду кримінального провадження має визначення за чинним КПК України то статус на стадії досудового провадження слідчого судді має декілька теоретичних обмежень. По-перше, функції учасників процесу на цих стадіях мають різні процесуальні інтереси. По-друге, змішення функції обвинувачення та правосуддя не повинно бути під час досудового провадження. По-третє, слідчий суддя обмежений фактичними доказами, які вказують на вину підозрюваного. Він має тільки факти, які йому надані слідчим, прокурором. Під час судового розгляду ці факти перевірені ретельно та визначені в обвинувальному акті. При цьому фактичні дані досудового розслідування під час отримання ухвали на проведення слідчих розшукових дій, які тимчасово обмежують права та свободи підозрюваного та докази, які встановлені на стадії судового провадження відрізняються. Обмеження процесуальних повноважень слідчого судді та колегіального суду потребують теоретичного обгрунтування та усунення практикою.

Ю.П. Аленін, В.Д. Бринцев, Ю.М. Грошевой, О.М. Овчаренко, О.В. Капліна,О.Г. Шило та ін. автори надали теоретичні положення статусу судді під час досудового провадження $[1 ; 5 ; 15 ; 17]$.

Сутність їх теоретичних пропозицій полягає в тому, що слідчий суддя, отримавши клопотання слідчого, прокурора та матеріали досудового провадження, повинен не тільки надати ухвалу щодо проведення слідчих розшукових дій, але отримати копію протоколу за результатами проведення для контролю виконання ухвали. Вони пропонували правовий розподіл процесу- альних функцій судді на стадії досудового та судового провадження.

К.Д. Анцифіров, О.М. Дроздов та ін. автори на підставі теоретичних положень судового процесу Великобританії запропонували процесуальний контроль судді за виконанням ухвали суду. В англійському процесі суддя здійснює контроль у рамках процедури попереднього слухання. Висновки суду про вину підозрюваного мають на меті не притягнення його до кримінальної відповідальності, а з'ясування можливості продовження процесу. Суддя надає доручення щодо початку кримінального обвинувачення або закриває кримінальне провадження [2; 12, с. 124].

ヘ.О. Богословська, Д.П. Великий,М.М. Ковтун, С.Б. Росинський, Д.В. Філін та ін. вважали, що функція судового контролю за діяльністю слідчого, прокурора є забезпечення процесуального захисту прав та свобод людини і громадянина $[4 ; 7 ; 14 ;$, 18 , с. $63 ; 19$, с. 129].

\section{Виклад загального матеріалу}

Процесуальні положення чинного законодавства встановлюють основні засади правової діяльності судді під час досудового та судового провадження. Для правового регулювання завдань та функціонального призначення суду можна виділити основні напрямки, а саме: процесуальні повноваження слідчого судді під час забезпечення функції судового контролю на стадії досудового провадження за органами досудового розслідування; судовий розгляд клопотання слідчого, прокурора про проведення слідчих розшукових дій, ухвалення процесуального рішення про дозвіл проведення слідчих розшукових дій, які тимчасово обмежують процесуальні права підозрюваного; забезпечення повноважень судді, колегіального суду щодо проведення судового розгляду та самостійного розв'язання процесуальних та матеріальних питань, які пов'язані 3 організаційними положеннями проведення судочинства; визначення елементів спрощеного судового розгляду 3 метою підвищення оперативності судового провадження; забезпечення публічних та приватних інтересів судового захисту прав 
і свобод учасників кримінального провадження.

Концептуальні ідеї міжнародно-правових стандартів у сфері забезпечення недоторканості особи є розширення повноважень суду по контролю за органами досудового розслідування на стадії досудового провадження. У разі виникнення конфліктних ситуацій між стороною обвинувачення та захисту слідчий суддя повинен вирішити цей конфлікт на підставі норм законності кримінального процесу.

Суддя не повинен підміняти процесуальну діяльність слідчого, прокурора, які виконують функцію обвинувачення. Кримінально правова кваліфікація правопорушення повинна відповідати обвинуваченню, яке визначає слідчий, прокурор. Основна функція суду $\epsilon$ правосуддя, яка має виконання завдань кримінального провадження.

Однак на стадії досудового провадження слідчий суддя має право надати слідчому своє процесуальне рішення щодо кваліфікації кримінального правопорушення на підставі чинного кримінального законодавства та визначити положення вина, яка передбачає застосування міри кримінального примусу та тимчасового обмеження прав i свобод підозрюваного.

Процесуальну діяльність слідчого судді на стадії досудового провадження можна визначити у наступних формах. Перша форма передбачає судовий розгляд клопотання слідчого, прокурора для проведення слідчих розшукових дій, які тимчасово обмежують процесуальні права та свободи підозрюваного. Друга форма включає до себе процесуальне рішення слідчого судді під час застосування міри запобіжного заходу у вигляді тримання під вартою.

Перша форма включає до себе проведення слідчих розшукових дій на підставі ухвали слідчого судді. Підставами для проведення слідчої (розшукової) дії 6 наявність достатніх відомостей, що вказують на можливість встановлення обставин кримінального правопорушення та вини підозрюваного. Слідчі розшукові дії, які тимчасово обмежують процесуальні права та обов'язки учасників кримінального про- вадження, проводяться на підставі ухвали слідчого судді. Перший аспект проведення слідчих розшукових дій на підставі слідчого судді передбачає проникнення до житла чи іншого володіння особи з метою встановлення доказів, які підтверджують вину підозрюваного у вчиненні кримінального правопорушення. Під житлом особи розуміється будь-яке приміщення, яке знаходиться у постійному чи тимчасовому володінні особи, незалежно від його призначення і правового статусу, та пристосоване для постійного або тимчасового проживання в ньому фізичних осіб, а також усі складові частини такого приміщення. Під іншим володінням особи розуміються транспортний засіб, земельна ділянка, гараж, інші будівлі чи приміщення побутового, службового, господарського, виробничого та іншого призначення тощо, які знаходяться у володінні особи.

Слідчий, прокурор складають клопотання до слідчого судді про можливість входу до житла чи іншого володіння особи. Слідчий суддя розглядає таке клопотання перевіряючи наявні підстави для проникнення до житла чи іншого володіння особи. Ухвала слідчого судді надається слідчому для виконання. Копію протоколу слідчий повинен надати слідчому судді для контролю виконання цієї ухвали.

Другий аспект надання клопотання слідчому судді включає до себе отримання ухвали для проведення обшуку. Обшук проводиться з метою виявлення та фіксації відомостей про обставини вчинення кримінального правопорушення, відшукання знаряддя кримінального правопорушення або майна, яке було здобуте у результаті його вчинення, а також встановлення місцезнаходження розшукуваних осіб. Слідчий суддя повинен розглянути у судовому засіданні клопотання про обшук у день його надходження за участю прокурора. Ухвала слідчого судді надається слідчому для виконання.

Новела чинного КПК України є отримання клопотання слідчого судді, згідно зі ст. 244 КПК України на залучення експерта. Слідчий для з'ясування обставин, що мають значення для кримінального про- 


\section{Кримінальне право, кримінальний процес та криміналістика}

вадження та необхідні спеціальні знання, звертається з клопотанням про проведення експертизи до слідчого судді. Під час розгляду клопотання слідчий суддя має право за клопотанням учасників розгляду або за власною ініціативою заслухати будь-якого свідка чи дослідити будь-які матеріали, що мають значення для вирішення клопотання. До ухвали слідчого судді про доручення проведення експертизи включаються запитання, поставлені експертові особою, яка звернулася 3 відповідним клопотанням. Слідчий суддя має право не включити до ухвали запитання, поставлені особою, яка звернулася 3 відповідним клопотанням, якщо відповіді на них не стосуються кримінального провадження або не мають значення для судового розгляду, обгрунтувавши таке рішення в ухвалі. Висновок експерта, залученого слідчим суддею, надається слідчому.

Друга форма передбачає судовий розгляд клопотання слідчого, прокурора про застосування міри запобіжного заходу. Слідчий суддя не розглядає питання доказування обставин кримінального правопорушення, а визначає застосування міри запобіжного заходу тримання під вартою на підставі кримінального закону, найчастіше ставить в основу ухвали склад тяжкого злочину. Щоб запобігти такого роду зловживанням, пропонуємо у клопотанні слідчого, прокурора до слідчого судді вказувати не тільки склад злочину, а приділяти увагу доказам, що підозрюваний причетний до здійснення кримінального правопорушення, а ставити перед судом питання щодо застосування міри запобіжного заходу взяття під варту. Висновок слідчого судді про взяття підозрюваного під варту встановлюється тільки при неможливості застосування іншої міри запобіжний заходу.

Пропонуємо ввести в чинне законодавство ст. 176 КПК України положення щодо додаткових обмежень для застосування запобіжний заходу взяття під варту відносно: категорії підозрюваних, які вчинили кримінальне правопорушення; виду інкримінованого злочину; правові наслідки та можливість їх усунення, наприклад відшкодування матеріальної шкоди, яка ви- значена на підставі кримінального правопорушення та ін.

Третя форма включає до себе процесуальні положення у разі надання слідчим суддею ухвали про проведення негласних слідчих (розшукових) дій. Слідчий суддя зобов'язаний розглянути клопотання про надання дозволу на проведення негласної слідчої (розшукової) дії протягом шести годин 3 моменту його отримання. Розгляд клопотання здійснюється за участю особи, яка подала клопотання. Слідчий суддя постановляє ухвалу про дозвіл на проведення негласної слідчої (розшукової) дії, якщо прокурор, слідчий доведе наявність достатніх підстав про вчинення кримінального злочину.

Практика ставить декілька питань отримання ухвали слідчого судді на проведення негласних слідчих (розшукових) дій. Перший елемент включає таємність проведення даної слідчої розшукової дії та відтік інформації. У цьому разі не тільки слідчий суддя має доступ до таємності проведення слідчої розшукової дії, але співробітники суду, які друкують ухвалу. Другий включає доступ до окремих моментів застосування оперативно-розшукової роботи оперативних підрозділів та розголошення їх перед слідчим суддею. Третій є доказовим визначенням отримання оперативної інформації та можливість їі процесуального оформлення як доказів.

Проведене анкетування слідчих, оперативних співробітників показало, що у $80 \%$ вони заперечують проти розголошення оперативних матеріалів перед іншими учасниками кримінального провадження. $15 \%$ вважали, що слідчий суддя повинен надавати ухвалу про проведення слідчих розшукових дій без ознайомлення з матеріалами оперативної розробки. Тільки 5\% вказали на законність надання ухвали слідчого судді під час проведення негласних слідчих (розшукових) дій.

\section{Висновок}

Проведення реформи кримінального процесуального законодавства надала нові елементи побудови кримінального процесу, який побудовано на основі змагальності. 
Запропоновано судовий контроль під час надання слідчим суддею ухвали у разі обмеження прав та свобод людини у кримінальному провадженні. Слідчий суддя отримав повноваження щодо перевірки результатів проведення негласних слідчих (розшукових) дій. Окремі елементи судового розгляду увійшли до стадії досудового провадження. Суддя отримав право проведення допиту під час досудового розслідування, а протокол допиту судді є доказ на стадії досудового провадження. Таким чином, процесуальні повноваження слідчого судді, що встановлені чинним законодавством відповідають міжнародним правовим нормам та надають імпульс не тільки для забезпечення прав, свобод та гарантій учасників кримінального провадження, а також встановлюють процесуальний контроль слідчого судді за проведення слідчих розшукових дій.

\section{Мітература}

1. Аленин Ю. П. Уголовнопроцессуальный кодекс Украины Науч. практ. комментарий / Ю. П. Аленин. Харків : Одисей, 2003. - 959 с.

2. Анциферов К. Д. Обвинительное начало и английский процесс / К. Д. Анциферов // Юридический вестник. - Москва, 1879. - C. 432.

3. Бажанов М.И. Производство дознания в органах милиции. /М.И. Бажанов, А.Д. Коган// -Х.: 1956. - 110с.

4. Богословська А. О. Апеляційне провадження: історія виникнення в Україні / ^. О. Богословська // Судова реформа в Україні: проблеми і перспективи: Х.: Юрінком Інтер, 2002. - С.206-209.

5. Брынцев В. Д. Судебная власть. Правосудие. Пути реформирования в Украине / В. Д. Брынцев. - Харьков : Основа, 1998. - 140 с.

6. Бережной O.I. Преюдиціальність судових рішень у кримінальних справах. /O.I. Бережной. - Х. СПД. ФО Вапнярчук M.M. 2006. - C. 28.

7. Великий Д. П. Единство и дифференциация уголовно- процессуальной формы : автореф. дис. ... канд. юрид. наук
: 12.00.09 / Д. П. Великий. - Москва, 2001. $20 \mathrm{c}$.

8. Гродзинский М.М. Государственный обвинитель в советском суде. /М.М. Гродзинский// - М.: Госюриздат. 1954.- 234 с.

9. Грошевой Ю.М. Нове у кримінально - процесуальному законодавстві України /Ю.М.Грошевой, Т.М.Мірошниченко// [для студ. та прак. вищ.навч.закл.] - Х.: Основа. 2002. - 110[11]c.

10. Гловюк I.B. Кримінально процесуальні функції: теорія, методологія та практика реалізації на основі положень Кримінального процесуального кодексу України /I.В. Гловюк - Одеса: Юридична літератуpa. 2015. - 712c.

11. Добровольская Т. Н. Изменение обвинения в судебных стадиях советского уголовного процесса / Т. Н. Добровольская. - Москва : Юрид. лит., 1977. - 151 с.

12. Дроздов О.М. Судові прецеденти - джерела кримінального процесуального права України / О.М. Дроздов/ Актуальні проблеми кримінального права, процесу та криміналістики - Одеса. Фенікс. 2010. -C. 124-127.

13. Зусь А.Д. Механизм правового регулирования. /А.Д.Зусь// Владивосток.: Дальневосточ. Владивост. УН-т. 1976. 190c.

14. Ковтун Н.Н. Судебный контроль в уголовном судопроизводстве России. /Н.Н.Ковтун// - Нижний Новгород.: Нижегододская правовая академия. 2002. -332с.

15. Капліна О.В. Кримінальний процес України: підручник / О.В. Капліна,Ю.М. Грошевой, О.В. Шило. - Х. Юрид. університет. 2013. - 820с.

16. Маляренко В. Т. Найпоширеніші помилки та порушення законів, які допускаються при провадженні дізнання і попереднього слідства / В. Т. Маляренко // Право України. - Київ : МЮ України, 2001. -№ 3. - С. 15 .

17. Овчаренко О.М. Доступність правосуддя та гарантії його реалізації /О.М. Овчаренко: монографія. - Харків. Право. 2008. - 280с.

18. Росинский С. Б. Нужен ли предварительный судебный контроль за производством следственных действий в 


\section{Кримінальне право, кримінальний процес та криміналістика}

жилище? / С. Б. Росинский. - Российский судья, 2009. - № 8. - С. 17-21.

19. Филин Д.В.Методологические проблемы процессуально-правовых исследований. / Д.В.Филин // Правовой аспект. -Воронеж. ВГУ. № 1. 2007 -С. 129-135.

20. Яновська О.Г. Концептуальні засади функціонування і розвитку змагального кримінального судочинства / О.Г. Яновська: монографія. - К. Прецедент. - 2011 308c.

\section{References}

1. Alenin Ju. P. Ugolovno-processual'nyj kodeks Ukrainy Nauch. prakt. kommentarij / Ju. P. Alenin. Harkiv : Odisej, 2003. - 959 s.

2. Anciferov K. D. Obvinitel'noe nachalo i anglijskij process / K. D. Anciferov // Juridicheskij vestnik. - Moskva, 1879. - S. 432.

3. Bazhanov M.I. Proizvodstvo doznanija v organah milicii. /M.I. Bazhanov, A.D. Kogan// -H.: 1956. - 110s.

4. Bogoslovs'ka L. O. Apeljacijne provadzhennja: istorija viniknennja v Ukraïni / L. O. Bogoslovs'ka // Sudova reforma v Ukraïni: problemi i perspektivi: H.: Jurinkom Inter, 2002. - S.206-209.

5. Bryncev V. D. Sudebnaja vlast'. Pravosudie. Puti reformirovanija v Ukraine / V. D. Bryncev. - Har'kov : Osnova, 1998. -$140 \mathrm{~s}$.

6. Berezhnoj O.I. Prejudicial'nist' sudovih rishen' u kriminal'nih spravah. /O.I. Berezhnoj. - H. SPD. FO Vapnjarchuk M.M. 2006. - S. 28.

7. Velikij D. P. Edinstvo i differenciacija ugolovno- processual'noj formy : avtoref. dis. ... kand. jurid. nauk : 12.00.09 / D. P. Velikij. Moskva, 2001. - 20 s.

8. Grodzinskij M.M. Gosudarstvennyj obvinitel' v sovetskom sude. /M.M. Grodzinskij// - M.: Gosjurizdat. 1954.234 s.

9. Groshevoj Ju.M. Nove u kriminal'no - procesual'nomu zakonodavstvi Ukraïni / Ju.M.Groshevoj, T.M.Miroshnichenko// [dlja stud. ta prak. vishh.navch.zakl.] - H.: Osnova. 2002. - $110[11] \mathrm{s}$.

10. Glovjuk I.V. Kriminal'no procesual'ni funkciï: teorija, metodologija ta praktika realizaciï na osnovi polozhen' Kriminal'nogo procesual'nogo kodeksu Ukraïni/I.V. Glovjuk - Odesa: Juridichna literatura. 2015. - 712s.

11. Dobrovol'skaja T. N. Izmenenie obvinenija $\mathrm{v}$ sudebnyh stadijah sovetskogo ugolovnogo processa / T. N. Dobrovol'skaja. Moskva : Jurid. lit., 1977. - 151 s.

12. Drozdov O.M. Sudovi precedenti dzherela kriminal'nogo procesual'nogo prava Ukraïni / O.M. Drozdov/ Aktual'ni problemi kriminal'nogo prava, procesu ta kriminalistiki - Odesa. Feniks. 2010. - S. 124-127.

13. Zus' L.D. Mehanizm pravovogo regulirovanija. /L.D.Zus'// Vladivostok.: Dal'nevostoch. Vladivost. Un-t. 1976. - 190s.

14. Kovtun N.N. Sudebnyj kontrol' v ugolovnom sudoproizvodstve Rossii. /N.N.Kovtun// -Nizhnij Novgorod.: Nizhegododskaja pravovaja akademija. 2002. $-332 \mathrm{~s}$.

15. Kaplina O.V. Kriminal'nij proces Ukraïni: pidruchnik / O.V. Kaplina,Ju.M. Groshevoj, O.V. Shilo. - H. Jurid. universitet. 2013. $-820 \mathrm{~s}$.

16. Maljarenko V. T. Najposhirenishi pomilki ta porushennja zakoniv, jaki dopuskajut'sja pri provadzhenni diznannja i poperedn'ogo slidstva / V. T. Maljarenko // Pravo Ukraïni. - Kiïv : MJu Ukraïni, 2001. -№ 3. - S. 15 .

17. Ovcharenko O.M. Dostupnist' pravosuddja ta garantiï jogo realizaciï /O.M. Ovcharenko: monografija. - Harkiv. Pravo. 2008. - 280s.

18. Rosinskij S. B. Nuzhen li predvaritel'nyj sudebnyj kontrol' za proizvodstvom sledstvennyh dejstvij v zhilishhe? /S. B. Rosinskij. - Rossijskij sud'ja, 2009. -№ 8. - S. 17-21.

19. Filin D.V.Metodologicheskie problemy processual'no-pravovyh issledovanij. / D.V.Filin // Pravovoj aspekt. -Voronezh. VGU. № 1. 2007 -S. 129-135.

20. Janovs'ka O.G. Konceptual'ni zasadi funkcionuvannja i rozvitku zmagal'nogo kriminal'nogo sudochinstva / O.G. Janovs'ka: monografija. - K. Precedent. - 2011 - 308s. 


\section{АНОТАЦІЯ}

Проведення реборми кримінального процеесуального законодавства надала нові елементи побудови кримінального процесу. Визначено процесуальні повноваження слідчого судді на стадї̈ досудового розслідування. Запропоновано судовий контроль під час надання слідчим суддею ухвали у разі обмеження прав та свобод людини у кримінальному провадженні. Визначено, що прочесуальні повноваження слідчого судді, встановлені чинним законодавством відповідағоть міжнародним правовим нормам та забезпечують виконання прав, свобод та гарантій учасників кримінального провадження, а також встановлюють процесуальний контроль слідчого суддi за проведення слідчих розшукових дій. Запропоновано теоретичні аспекти та практичне вирішення даних питань та внесення змін до иинного законодавства.

Ключові слова: механізм, клопотання, слідчі розиукові дї, гарантї, статус, слідчий, прокурор, слідчий суддя, учасник досудового розслідування.

\section{PROCEDURAL POWERS OF THE INVESTIGATING JUDGE}

The reform of the criminal procedural legislation is provided new elements for the construction of the criminal process. The procedural powers of an investigator judge at the stage of pre-trial investigation have been determined. Proposed judicial control when the investigating judge provides a decision in case of limitation of human rights and freedoms in criminal proceedings have been done. It was determined that the procedural powers of an investigating judge established by the current legislation comply with international legal standards and ensure the implementation of the rights, freedoms and guarantees of participants in criminal proceedings, as well as establish procedural control of the investigating judge for the conduct of investigative search actions. Theoretical aspects and practical solutions to these issues and amendments to the current legislation are proposed.

Key words: mechanism, investigative search actions, guarantees, status, investigator, prosecutor, investigating judge, participant of pre-trial investigation. 